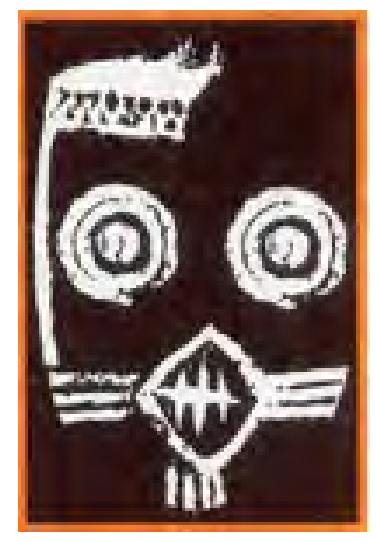

The Politics of Permanent Conflict: Farmer-Herder Conflicts in Northern Cameroon Author(s): Mark Moritz

Source: Canadian Journal of African Studies / Revue Canadienne des Études Africaines, Vol. 40, No. 1 (2006), pp. 101-126

Published by: Canadian Association of African Studies

Stable URL: http://www.jstor.org/stable/25433868

Accessed: 21/01/2010 11:41

Your use of the JSTOR archive indicates your acceptance of JSTOR's Terms and Conditions of Use, available at http://www.jstor.org/page/info/about/policies/terms.jsp. JSTOR's Terms and Conditions of Use provides, in part, that unless you have obtained prior permission, you may not download an entire issue of a journal or multiple copies of articles, and you may use content in the JSTOR archive only for your personal, non-commercial use.

Please contact the publisher regarding any further use of this work. Publisher contact information may be obtained at http://www.jstor.org/action/showPublisher?publisherCode=caas.

Each copy of any part of a JSTOR transmission must contain the same copyright notice that appears on the screen or printed page of such transmission.

JSTOR is a not-for-profit service that helps scholars, researchers, and students discover, use, and build upon a wide range of content in a trusted digital archive. We use information technology and tools to increase productivity and facilitate new forms of scholarship. For more information about JSTOR, please contact support@ jstor.org.

Canadian Association of African Studies is collaborating with JSTOR to digitize, preserve and extend access to Canadian Journal of African Studies / Revue Canadienne des Etudes Africaines. 


\title{
The Politics of Permanent Conflict: Farmer- Herder Conflicts in Northern Cameroon
}

\author{
Mark Moritz
}

\section{Résumé}

Cet article suggère qu'il est nécessaire, pour arriver à une meilleure compréhension des conflits entre fermiers et bergers en Afrique de l'Ouest, de considérer de manière explicite ce que les acteurs individuels ont à gagner de ces conflits. Nous avancerons notre compréhension du rôle que jouent les autorités dans la perpétuation des combats pour les ressources naturelles en intégrant la perspective des "politiques du ventre" dans l'analyse des conflits entre fermiers et bergers. Un combat entre les fermiers migrants Tupuri et les bergers nomades Fulße pour les terrains de camping dans le Grand Nord Camerounais montre la manière dont les autorités administratives traditionnelles et régionales ont savamment et habilement évité toute résolution du conflit. Ils avaient plus à gagner par la perpétuation du conflit que par sa résolution. Malgré la devise "la politique d'abord" les écologistes politiques n'ont généralement pas réussi à incorporer systématiquement la politique du conflit permanent.

\section{Introduction}

To come to a better understanding of farmer-herder conflicts in West Africa, it is important to consider more explicitly what individual actors have to gain from these conflicts. A better understanding of these conflicts is urgent because they are likely to increase and become more violent in West Africa in the near future. Policies and programs aimed at preventing or resolving these

I am grateful to Leslie Moore, Ruth Noorduyn, Brett O'Bannon and Paul Scholte for their insightful comments. I also wish to thank people at the Center for African Studies at Stanford, with whom I discussed parts of this paper, in addition to Paul Scholte and Saidou Kari for their collaboration. 
conflicts are doomed to fail, however, if they are based on erroneous assumptions and incomplete understandings of farmer-herder conflicts. Recent studies of farmer-herder relations in West Africa have challenged the widely held assumptions that farmer-herder relations were more symbiotic in the past (Breusers, Nederlof, and Rheenen 1998); that these relations have become increasingly more violent (Hussein, Sumberg, and Seddon 2000); and that scarcity of natural resources is the main cause of these conflicts (Turner 2002), and underscored the need for empirical evidence and careful analysis. In their discussion of Mossi farmers and Fulße herders, Breusers et al. (1998) have argued that one cannot study farmer-herder relationships as dichotomous relationships between two bounded ethnic groups, showing that there are conflicting interests among Mossi farmers and that farmer-herder relations are, in fact, multistranded. Although Fulße herders are presented as one homogenous group, the strength of their argument lies in their analysis of the behavior of individual Mossi farmers. Their story of Ousmane stands out. Ousmane publicly called for 25000 FCFA compensation from a Fulße herder held responsible for damaging the millet crop of a fellow Mossi, even though Ousmane had to contribute himself to that compensation because he had entrusted animals in the Fulße herd that had caused the damage /although I suspect that Ousmane's animals did not feed off the millet, but I will come back to that later). It is through the focus on the decision-making and behavior of individual Mossi farmers that Breusers et al. arrive at a deeper understanding of ostensibly conflictual farmer-herder relations.

I will argue that when we systematically apply an analytical focus on the individual actions and decision-making of all parties involved in these conflicts, we will greatly improve our understanding of farmer-herder conflicts in general. This analytical approach entails methodological individualism, evaluation of costs and benefits of individual actions / which can be material, political, social, or symbolicl, the supposition that individuals are strategic actors who take advantage of opportunities (but not always), and a reliance on empirical and ethnographic data (instead of reasonable assumptions and generalizations). An in-depth discussion of one particular conflict between nomadic Fulße pastoralists and migrant Tupuri farmers in Mayo Kobo in the Far North Province of Cameroon demonstrates the value of such an analytical approach. 
Drawing on data collected during my research projects with Fulße pastoralists in the Far North in 1996 in collaboration with Paul Scholte and Saidou Kari of the Waza Logone Project and in 1999 and 2000-01 independently, as well as material collected by others who have reported on the same conflict (Wassouni 2001; van der Ploeg 2001), I show that traditional and regional administrative authorities purposefully and masterfully avoided conflict resolution, as they had to gain more by perpetuation of the conflict than by its resolution. Drawing from recent studies of African political systems (van de Walle 2001; Bayart 1993; Bayart, Ellis, and Hibou 1999; Chabal and Daloz 1999|, I will discuss how authorities use the current institutional ambiguity in land tenure regimes to "fill their bellies" at the expense of both Fulße pastoralists and Tupuri farmers. I will also argue that despite the motto of "politics first," political ecologists generally have failed to incorporate systematically and explicitly the "politics of permanent conflict" (borrowing from, van de Walle 2001), which is based on the premise that authorities are rational actors who strategically pursue their interests. ${ }^{1}$

\section{An Actor-Oriented Approach}

Actor-oriented analytical approaches are not new to ecological and environmental theory and research; the use of an actor-oriented approach in these research paradigms does not imply that context or systems are ignored (Vayda 1983; de Groot 1998; Long and Long 1992). De Groot, for example, employs an Action-in-Context model to analyze and explain environmental problems, starting with the options and motivations of different actors, contextualized within the "actors' fields," that is, the underlying power relations, culture, and markets in society, progressively following the causal chain upwards (de Groot 1998, 33). I will use a similar actororiented approach here, combining a concern for context with a form of methodological individualism that is at the heart of rational actor theory, in order to arrive at a better understanding of farmer-herder conflicts.

I am not using a model of rational actors defined in the narrowest economical sense as individuals who are motivated by self-interest, perfectly informed, always calculating costs and benefits, and maximizing their way through life (Ensminger 1992, 12), or, as Sen called them, "social morons" (1977). Actor-oriented 
paradigms, in particular rational actor models, have often been criticized for being too individualistic and not paying enough attention to structural constraints, whether these are cognitive (Camerer 1995), social (Granovetter 1985), political (McGlynn and Tuden 1991), or cultural (LeVine 1984, 79-80). Anthropologists have argued therefore for a more relativist definition of rational actors as humans being rational within a particular cultural and economic context. As Plattner notes,

Individuals in any culture are seen as fully "rational," in the sense that their solutions to their economic problems make sense once the many constraints (social, cultural, cognitive, and political, as well as economic) that individuals must take into account are understood $(1989, \mathrm{xi})$.

The disadvantage of this relativist approach is the loss of the sense of individuals as strategic actors who take advantage of opportunities. Bourdieu's theory of practice encompasses the constraints on individual behavior without doing away with individual agency or a strategic action (1980). Bourdieu argued that not rational calculation but the dispositions of habitus, internalized implicitly and inculcated explicitly during socialization, make people do what they do. The habitus, or feel for the game, informs the everyday practice of individuals, which means that in practice people improvise and "work with rules and norms in a forward thinking strategic way, using their knowledge to pursue their interests" (Wilk 1996, 142). In practice theory, people are strategic actors, even when their practices are grounded in the habitus and contingent on local social, cultural, and political structures. I will show that the use of such an actor-oriented approach that assumes individuals to be strategic actors who take advantage of opportunities will increase our understanding of farmer-herder conflicts. ${ }^{2}$

\section{Politics of Permanent Conflict}

The premise that people are strategic actors who take advantage of opportunities, even if it means breaking rules and taking advantage of others, is common in the recent literature on African political systems (Chabal and Daloz 1999; Bayart 1993; van de Walle 2001; Bayart, Ellis, and Hibou 1999; Cruise O'Brien, Dunn, and Rathbone 1989|. These studies of the African state use an analytical approach of methodological individualism that assumes individuals are maximizing and strategizing actors. In fact, rational actor theory 
fits well the political logic of the "politics of the belly" (Bayart 1993; Bayart, Ellis, and Hibou 1999, 34). The politics of the belly

... is a Cameroonian expression which has numerous equivalents throughout sub-Saharan Africa. It denotes at the same time the accumulation of wealth through tenure of political power (implied in the proverb "the goat grazes wherever it is tied"), the symbolic reference to family lineage and to witchcraft, and the physical corpulence which is felt is appropriate in "big men" or powerful women (Bayart, Ellis, and Hibou 1999, 8). Bayart (1993) has argued that the politics of the belly is a complex mode of government, rooted in subterranean networks of family ties and patron and client networks in what he calls l'etat rhizome. It is also referred to as the neopatrimonial state (van de Walle 2001). In this mode of government, patrimonial practices coexist with the modern bureaucracy of Weber's legal-rational state. As van de Walle argues,

... outwardly the state has all the trappings of a Weberian rational-legal system, with written laws and a constitutional order. However, this official order is constantly subverted by a patrimonial logic, in which officeholders systematically appropriate public resources for their own uses and political authority is largely based on clientelist practices, including patronage, various forms of rent-seeking, and prebendalism (2001, 51-52).

Some scholars conceive of the African state as a "shadow state" in which the modern bureaucracy is just an empty façade (Reno 1995; Chabal and Daloz 1999). Others have argued that it is better to think of African states as hybrid regimes in which personal rule coexists with a modern bureaucracy (van de Walle 2001). There are budgets and laws, but these

... can be thought of as public goods on which neopatrimonial interests attempt to free-ride ... rent-seeking and much corruption require that the state set rules that are generally followed, so that the rents created can be abused for personal profit (van de Walle 2001, 128).

Chabal and Daloz (1999) imply that neopatrimonial networks work as redistributive systems that also benefit poorer clients in their suggestively titled book Africa Works. But in reality, little trickles down and most remains in the few hands at the top /van de Walle 2001, 119) where it is used to forge alliances across different 
elites in "hegemonial exchanges" or "reciprocal assimilation of elites" (Rothchild 1985; Bayart 1993). For most Africans, the neopatrimonial state does not lead to significant wealth or empowerment (van de Walle 2001, 120). On the contrary, the hybriditization of personal rule and modern bureaucracy creates greater ambiguity and uncertainty that leaves the poor powerless and dependent on the whims or mètis of the state's elites and bureaucrats. The notion of mètis, discussed by Bayart (1999) as an aspect of African individualism, is about achieving success by playing with rather than by the rules of the game, that is, through trickery. However, unlike in African folk stories, in which the trickster uses its mètis to gain victory over the powerful, in the neopatrimonial state it is the powerful elite who use their mètis to exploit institutional ambiguity and take advantage of the poor and powerless (see also Cruise O'Brien, Dunn, and Rathbone 1989, 6).

The use of public resources for personal enrichment, that is, the privatization of the state, by not only the elite but by every group with access to the state, has led to a weakening of the state: underfinanced state structures; almost no revenues from taxes, tariffs, and licenses; weak administrative capacities; and thus no resources to undertake developmental policy (Cruise O'Brien, Dunn, and Rathbone 1989; van de Walle 2001). In turn, this "has facilitated various rent-seeking and corrupt practices," and "state agents who wish to undertake these practices have a clear interest in weakening the state's administrative capacities" (van de Walle 2001, 135). It is not just that capacities of African states are weak, they are weak because the politics of the belly is the dominant mode of government and the logic that guides the behavior of individual bureaucrats and politicians in many African states.

\section{Belly Politics First}

"Putting politics first" is the motto of an analytical approach called political ecology which embeds ecological concerns in political analyses (Bryant and Bailey 1997; Blaikie and Brookfield 1987). The approach of political ecology

... combines the concerns of ecology and a broadly defined political economy. Together this encompasses the constantly shifting dialectic between society and land-based resources, and also within classes and groups within society itself (Blaikie and Brookfield 1987, 17). 
The diverse and interdisciplinary field of political ecology has produced a number of high-quality studies that have significantly contributed to a greater understanding of the relationships between nature and social relations, and in particular how larger politicaleconomic processes affect this relationship (for reviews see Watts 2000; Bryant 1998; Peluso and Watts 2001). Vayda and Walters have argued that some political ecologists pay more attention to politics than to ecology and that this is resulting in "politics without ecology" $(1999,167)$. In contrast, I argue here that studies of natural resource management in West Africa have not paid enough attention to politics, or the right sort of politics: "belly politics."

In much of the scholarly and development literature on natural resource management in West Africa, the image of the state is quite different from the one discussed in the recent political science literature. In the former, the analysis of the role of the state in natural resource management often focuses on the official laws and policies of an ideal bureaucratic state, rather than on bureaucrats' actual behavior in a neopatrimonial state. This focus results in unrealistic expectations of "the state." Subsequent failures of the state to manage natural resources (and the conflicts there over) are then explained as a weakness of the state that can be remedied through institution building or financial support. The assumption is that authorities follow the laws of land and do not engage in rentseeking behavior or that it is incidental and not a mode of government. When the "politics of disorder" are discussed, they are worded in terms of plurality, ambiguity, complexity, and uncertainty in the governing of natural resources (Benjaminsen and Lund 2001, 12; Mehta et al. 1999, 10). However, I think that these terms conceal more than they reveal, and inhibit better understanding of farmer-herder conflicts - unless we examine more closely how individual actors negotiate the institutional ambiguity and complexity to pursue their own interests. ${ }^{3}$

The lack of integration of the politics of the belly in political ecology analysis also signals theoretical and analytical differences with recent literature on the African state; political ecologists focus more on structure rather than agency, and this often translates into a focus on formal institutions instead of individual behavior (see also Bryant 1998, 81-82; Horowitz 2003, 27). The politics of the belly are not formalized, but they are institutionalized. Practice theorists would argue that the practices of individual 
bureaucrats constitute the structure of institutions. In their discussion paper, Mehta et al. integrate practice theory in the analysis of natural resource management and argue:

... the new insights on the overlapping nature of institutions in legal pluralism help us to comprehend how interpretations are negotiated across institutional arenas, with law emerging less as fixed rules than as practice worked out in context. Thus processes of mediation, bargaining, conflict and power become key in institutional landscapes where uncertainties prevail $(1999,26)$.

Even though Mehta et al. (1999) discuss power differences in their discussion of institutions and uncertainty in natural resource management, there is no explicit acknowledgement that the institutional landscape that emerges, at least in West Africa, is that of the politics of the belly in which smallholders are steadily losing out to the wealthy, powerful, and better connected elite, who are much better positioned in these "negotiations." This point is well noted by Peters who argues: "the positive aspects of ambiguity and indeterminacy in Africa's "land question" may be over-emphasized to the point of ignoring or deflecting research and policy away from growing inequity in access to and use of land" $(2002,56) .^{4}$ Natural resources have to be seen in the same light as other public resources of the state: a public good that can be exploited by elites with access to the state for personal gain.

\section{The Mayo Kobo Conflict}

The Mayo Kobo conflict illustrates well how authorities used competition for public lands to create and perpetuate conflicts between migrant Tupuri farmers and nomadic Fulße pastoralists for personal gain. The conflict started when Tupuri farmers cleared the campsites of nomadic Fulße on the banks of the seasonal river Mayo Kobo. Subsequent protests from the Fulße led to involvement of various traditional and state authorities, who generally decided in their favor, even though this did not lead to the removal of the farmers. In fact, the Tupuri settlement continued to grow in the three years that the conflict lasted.

To illuminate the role of authorities in the Mayo Kobo conflict, I am using an analytical approach of methodological individualism that considers the costs and benefits of individual actions (and inactions| and assumes individuals to be strategic actors who take 
advantage of opportunities. The problem of studying the "politics of permanent conflict" and the application of methodological individualism lies in the collection of reliable data on the neopatrimonial activities of the elite (Bayart, Ellis, and Hibou 1999) and on conflicts in general (see, Roy 1994; Hagberg 2001, 54). This study relies in part on drawing inferences from contradictory accounts, incomplete information, and partial observations (see also Hansen 2003,208 ), and it is therefore maybe more appropriate to write about an interpretative framework. The advantage of discussing the Mayo Kobo conflict is that two other researchers have studied the same conflict (and that thus more, but still incomplete and contradictory, information is available) (van der Ploeg 2001; Wassouni 2001). I am also using data from other farmer-herder conflicts in the Far North as well as the extensive literature on politics and society in Cameroon in order to understand the actions and motivations of actors involved in the conflict and situate the conflict in the ecological, socioeconomic, political, and historical setting of the Diamare in which Mayo Kobo is located. ${ }^{5}$ I present the "facts" of the Mayo Kobo conflict in indented blocks and analysis in regular text to signal distinction between facts agreed upon by the researchers and my interpretations of the actions of the authorities.

The Mayo Kobo conflict started in the 1996 rainy season when three migratory groups of nomadic Fulße Mare'en (approximately thirty-five nomadic households) returned to the Diamaré plains to find their customary rainy season campsites at the banks of the Mayo Kobo occupied by seven migrant Tupuri families. ${ }^{6}$ The Tupuri had come in search of land to cultivate sorghum. The Mayo Kobo campsites were desirable sites for cultivation because of the fertile layers of cattle dung, especially since these campsites had been used for twenty-two years, but also because they were relatively easy to clear as they were located at higher elevated sandy soils with only a few trees.

There is no immediate shortage of land in the Moulvoudaye sous-prefecture. It has some of the lowest population densities in the province, which is one of the reasons why nomadic pastoralists have their rainy season camps in the Mindif and Moulvoudaye sous-prefectures (Seignobos et Iyébi-Mandjek 2000). However, there is competition for the campsites between migrant Tupuri 
farmers and nomadic Fulße pastoralists; the former value the campsites for their fertility, the latter for elevation and proximity to water and pastures. Because Tupuri generally set up compounds next to the fields they clear, and campsites are far away from established villages, migrant farmers are not in direct competition for land with autochthonous farmers - only with nomadic Fulße pastoralists who are there "only" in the rainy season. The seven families that occupied the Mayo Kobo sites were part of a larger migration from the area of Doukoula, the Tupuri "homeland" in the southeast corner of the Far North province. They were pushed by a lack of arable land in this densely populated and intensively cultivated area. Tupuri have been relocating to the Mindif and Moulvoudaye sous-prefectures since at least the 1930s, and surpassed the agro-pastoral Fulße population in numbers in the 1950s, such that Seignobos et Iyébi-Mandjek (2000) write about a "veritable Tupuri colonialization," 150 years after the Fulße conquered the land in a jihad (holy war).

Early in the nineteenth century, the Fulße conquered a number of populations in the part of the Far North Province that is called the Diamaré. The conquest took place under the cover of a larger Fulße jihad that was started in Sokoto in 1804 by sheikh 'Uthmân dan Fodio (Seignobos et Iyébi-Mandjek 2000). Scholars have argued that the jihad and conquest of the Diamare served as legitimatization of other pursuits; some of the Fulße were in search of slaves, others in search of pastures (Seignobos et Iyébi-Mandjek 2000). The Fulße emirates established in the Diamare after the jihad (Maroua, Mindif, Kalfou, and Bogo emirates) were loosely organized in the segmentary state of the Sokoto Caliphate as vassal provinces of the Adamawa emirate. The emirates resembled the highly centralized and hierarchical medieval Muslim caliphates (Azarya 1978). At the top of the hierarchy was the laamiiDo (plural laamiiBel, who governed his territory via secondary and tertiary chiefs, lawan'en and jawruBe respectively (singular lawan and jawro). The political system of the Fulße emirates was later incorporated in the colonial and postcolonial state.

Although the Tupuri were never subjugated by the Fulße, they were involved in the hundred years of war between the Fulße emirates and neighboring populations following the jihad (Beauvilain 1989; Issa et Adama 2002). The tension and mutual distrust between the two ethnic groups is historically rooted and 
was frequently expressed in the discourse of the parties involved in the Mayo Kobo conflict (van der Ploeg 2001), even though the nomadic Fulße Mare'en are not descendants of the Fulße that established the emirates and fought the hundred-year war.

The Fulße Mare'en stay in the Diamaré three months out of the year. They and other transhumant pastoralists in the Far North Province oscillate between two distinct ecological zones that characterize the province: bush savanna in the southern grades and treeless grasslands in the Logone flood plain, which is situated in the north and receives slightly lower rainfall and a shorter rainy season. The seasonal flooding of the Logone flood plain, triggering grass production well into the dry season, makes the zone one of the most important dry season rangelands in the Chad Basin. Pastoralists from Cameroon and neighboring Nigeria and Niger trek each November to the Logone flood plain when the water retreats to exploit the excellent quantity and quality of the rangelands. At the start of the rainy season, Cameroonian transhumant pastoralists return to the higher elevated plains of the Diamaré, while pastoralists from neighboring countries return to their respective countries. The Logone flood plain and the Diamare plains thus form complementary resources in the pastoral ecosystem of the Far North, the former providing pastures in the dry season, the latter in the rainy season.

Even though the Fulße Mare'en stay only three months out of the year in the Diamaré, they are integrated into the political system of the Fulße lamidats (which is the commonly used French word for emirate or territory governed by the laamiiDol. The migratory groups of the Fulße Mare'en are considered small villages or quarters within the lamidat under the leadership of an ardo, similar to how villages of agro-pastoral Fulße and other agricultural groups such as the Giziga, Kanuri, Tupuri, and Mundang were headed by a jawro. Nomadic pastoralists and the Fulße authorities had a "nomadic contract" in which nomads' access to rangelands and personal safety were protected by the laamiiDo or lawan in exchange for tax and tribute (Moritz, Scholte, and Kari 2002). LaamiiBe were generally good in protecting the grazing rights of nomadic pastoralists as they had a clear interest in ensuring that nomads returned to their territories because of the taxes they paid. Through their association with the Fulße laamiiBe, Fulße Mare'en were also integrated in the bureaucratic structure 
of the state. They are inscribed on the roles of the municipality in the lamidat where they spend the rainy season and pay their poll taxes /rather than in the dry season transhumance area of the Logone flood plain). However, over the last two decades, especially with the political reforms, including the introduction of the multiparty democracy and decentralization in the 1990s, this arrangement between nomadic Fulße and the laamiiBe has come under pressure, as the latter have gradually lost power, not only to the state and its agents but also to their own subordinates: the lawan'en and jawruBe (Moritz, Scholte, and Kari 2002). This has led to greater ambiguity and insecurity in the tenure situation for nomadic pastoralists in the Diamare since multiple authorities now claim to "own" the land.

When the three Fulße Mare'en migratory groups found their campsites occupied in June of 1996, they first went to the lawan of Daram with whom they had a "contract" and who customarily had some authority over the Mayo Kobo lands. ${ }^{7}$ The nomads argued that the Tupuri farmers had not only taken their campsites but also that their "colonialization" led to a parcelization of the surrounding rangelands, which rendered them un-exploitable because of increased risks of crop damage. The lawan was sympathetic to their case and expressed anger that migrant Tupuri farmers had cleared fields in his territory without his permission. But the lawan also said that he could do little because he no longer had the power to remove them. He suggested the Fulße Mare'en to take their case to the laamiiDo in Mindif, his superior in the hierarchy of the traditional Fulße system, and the sous-préfet in Moulvoudaye, his superior in the state's administration. The migrant Tupuri farmers who had cleared the fields, on the other hand, proceeded as if Mayo Kobo was located in the neighboring lawanat and went to the lawan of Kobo who was partial to the agricultural populations. The lawan had repeatedly declared that nomadic pastoralists were not welcome in his territory because he did not profit from their presence. ${ }^{8}$ The lawan of Kobo also suggested the Tupuri to take their case to the souspréfet in Moulvoudaye.

The location of Mayo Kobo at the banks of the small seasonal river is partly responsible for some uncertainty about which of the two lawan'en had authority over the campsites because the river 
forms the boundary between the Kobo and Daram lawanats (French for the territory governed by a lawan). But this was not a major problem since both lawan'en declined to make a decision and instead sent their "clients" to higher-level authorities. The problem of ambiguity lies in the fact that it was unclear who had the effective authority over the campsites and grazing lands of Mayo Kobo: the laamiiDo of Mindif or the sous-préfet of Moulvoudaye.

In the precolonial past, all lands were owned by the laamiiDo and there was no distinction between public and private lands in the lamidats. The traditional Fulße authorities - laamiiDo, lawan, and jawro - owned all lands. Farmers had only temporary use rights and when they left land fallow the Fulße authorities could reclaim it. Under colonial rule, all the so-called "vacant and ownerless" lands were considered public lands and administered by the colonial administration, even though in the Far North traditional Fulße authorities remained de facto "owners" of the land. In 1959, one year before independence, the colonial administration enacted a law that formally returned control to customary authorities. A few years later, however, new laws returned control over these lands to the state, and this was reaffirmed in the 1974 land reform act, which officially abolished customary tenure systems and introduced individual, state, and national lands (Fisiy 1992; van den Berg 1997, 190-91). The allocation of national (public) lands officially became the prerogative of the sous-préfet, but again, effectively little changed and traditional institutions continued to guide land tenure systems in the Far North. Traditional Fulße authorities continued to be the "owners" of the land from whom farmers ask permission to clear land or buy fallow fields (see also van den Berg $1997,200)$. In recent decades, however, the power of traditional Fulße authorities has diminished (Moritz, Scholte, and Kari 2002). Sous-préfets, the official "owners" of the land, are increasingly asserting their authority over national lands and are now often referred to as chef de terre, indicating that they are gaining more and more control over the land.

After their initial visit to the lawan of Kobo, the Tupuri farmers were slower to pursue a hearing with the Moulvoudaye sous-prefet as the threat of immediate removal subsided. The initiative was with the Fulße Mare'en, who tried to reclaim their campsites. After multiple visits to the lawan of Daram, the Fulße Mare'en were received in July by the sous-préfet in 
Moulvoudaye. (The laamiiDo of Mindif was at that time in Yaoundé for a meeting of the national organization of traditional authorities. The Fulße Mare'en could not wait for his return and had decided to go directly to the sous-préfet.) The lawan of Daram was actively involved in organizing a hearing for the Fulße Mare'en at the sous-prefecture in Moulvoudaye. None of the Fulße Mare'en spoke French, one of the national languages, but the lawan of Daram, who acted as their broker, did. The nomads had paid him gooro to ensure their case was heard by the sous-préfet (gooro, Fulfulde for kola nut, is a term frequently used as euphemism for bribes and rents). The Fulße Mare'en represented by the lawan of Daram demanded from the sous-préfet the immediate removal of the Tupuri farmers. In response, the sous-préfet chose to send a delegation to the campsites and interrogate the Tupuri farmers and Fulße Mare'en at the site. The delegation consisted of the sous-préfet himself, the lawan of Daram, the commander of the brigade, and the veterinarian of Moulvoudaye. The delegation, which was "financed" by the Fulße Mare'en, interviewed the parties involved at the site. After consultation with the other members of the delegation, the sous-prefet decided that the nomadic pastoralists had legitimate claims to the campsites and that the farmers had to leave. However, the sous-prefet also argued that nothing could be done at that time because the farmers had already sown their sorghum - to chase them would condemn them to hunger and that would be morally wrong (van der Ploeg 2001).

The Fulße Mare'en paid the transport of the delegation to the campsites; this meant not only the fuel for the car but also the "motivation" for the members of the delegation in the car. ${ }^{9}$ In fact, practically each step in the judiciary pathway involved some transfer of cash to the authorities. The Fulße Mare'en paid the lawan (and through him others as well) to ensure that the judiciary process continued. But these payments did not necessarily ensure that justice was done in their favor.

During the interviews at the site, the Tupuri farmers complained that Fulße cattle entered their fields and destroyed their crops. In response, the sous-prefet decided that in this case it was the responsibility of the farmers to protect their crop from incursions from Fulße cattle. In fact, the sous-préfet said 
that the nomads could camp right next to the fields and did not have to worry about crop damage, which already had occurred several times and had led to fights between the Tupuri and the Fulße Mare'en.

This decision of the sous-prefet was a recipe for continuing conflicts between Tupuri farmers and nomadic herders over crop damage and a possible violent escalation of the Mayo Kobo conflict. ${ }^{10}$ The situation did not improve after the delegation's visit and decisions. In fact, the decisions of the sous-préfet maintained the status quo. After all the efforts and expenses of both Tupuri and Fulße Mare'en, nothing had changed. This became even more evident in the years following.

When the Fulße Mare'en returned to Mayo Kobo from their transhumance to the Logone flood plain in the rainy season of 1997 they found not only that the Tupuri farmers were still on their campsites, but also that the settlement had grown by three families. Again, the Fulße Mare'en pursued the case at the lawan and the sous-préfet, and again, the authorities sided with the nomadic pastoralists by reaffirming their earlier decisions but effectively did not undertake any action. The story repeated itself in 1998, but with one important change: the lawan of Daram had named one of the farmers as jawro of the Tupuri settlement at Mayo Kobo (van der Ploeg 2001). He thereby no longer simply condoned the actions of the migrant farmers but legalized their settlement. It became clear that the lawan was playing both sides in the conflict.

In January 1996, the party dominated by Tupuri, the MDR (Movement for the Defense of the Republic) won mayoral elections in three major towns in the southeast of the province: Moulvoudaye, Guidiguis, and Doukoula (Mouiche 2000). The MDR, led by a Tupuri Dakolé Daïssala, has presented itself as the political party for the Kirdi - a term used by colonial administrators for non-Fulße and non-Muslim populations in the Far North. The term has been appropriated by Kirdi populations themselves to protest the exclusivity and discrimination by the Muslim Fulße (particularly during the regime of the first president Ahidjo). Kirditude represents a political and cultural movement that is growing in importance in regional and national politics (Mouiche 2000). It is unclear whether the election results bolstered the migrant Tupuri farmers in their land grab, but traditional Fulße 
authorities certainly perceived these results as indicators of a threat to their power and the Tupuri as force to reckon with. It may have been an opportunistic move on the part of the lawan to side with the Tupuri, who were becoming an important constituent in his territory. ${ }^{11}$

As the conflict continued, it became clear that the lawan of Daram had given permission to migrant Tupuri farmers in 1996 to clear the nomadic campsites at Mayo Kobo /though not to all farmers), knowing that conflicts would arise from which he could profit as broker for the nomads who lost their campsites. One of the nomads characterized the lawan's strategy as: "he had created a cow that could be milked." The Tupuri farmers had each paid the lawan of Daram 20000 FCFA in addition to an unknown amount that one of their leaders had paid the lawan and the sous-préfet (van der Ploeg 2001). The reason the lawan of Daram was initially angry when the nomadic pastoralists brought their case to him in 1996 was that he found out that some of the farmers had not paid him.

The Mayo Kobo conflict ended in 1999 due to a combination of reasons and despite the efforts of the authorities. Migrating elephants from Waza National Park had come through the area destroying all the fields and crops in their path. The fields in Mayo Kobo were particularly vulnerable to elephant damages since they were relatively isolated and far from the population centers generally avoided by the elephants. The crop losses suffered by farmers were worse than those caused by Fulße cattle. A number of Tupuri left and moved elsewhere because of the threat of future destruction (van der Ploeg 2001), but the Fulße Mare'en remained in the area as their cattle were easily habituated to the elephants.

The previous year, a special unit of the security forces commonly referred to as the anti-gang had been sent to the Far North because of growing insecurity resulting from banditry. The anti-gang operated outside the law and summarily executed suspected bandits, ordinary criminals, and lower-ranking traditional authorities that protected them (see also Amnesty International 1998). Two young Tupuri men from the Mayo Kobo settlement who were suspected of theft of donkeys from the displaced nomadic Fulße were taken by the anti-gang in June 1999, never to be seen again (van der Ploeg 2001, 109). The actions of the anti-gang unit created an atmosphere of fear and intimidated both 
parties involved in the Mayo Kobo conflict. The destruction by the elephants and the anti-gang sounded the end of the conflict in 1999. The nomads finally accepted the futility of pursuing their case after three years of being subjected to the authorities' mètis and moved to neighboring Kolara, leaving their campsites to the remaining Tupuri.

\section{Conclusion}

I have argued that natural resources have to be considered public goods of the state that can be used by the authorities for personal gain. However, the problem is, as one traditional chief succinctly stated, that le chef ne mange pas la terre / the chief cannot eat the land); that is, lands have no value in themselves for the authorities, who, like farmers, must make them productive (mise en valeur). One way authorities make public lands productive in the Far North of Cameroon is by exploiting competing interests over natural resources to create, mediate, and perpetuate conflicts over land. ${ }^{12}$ But these politics of permanent conflict are not always transparent. ${ }^{13}$ Outwardly, the authorities in the Mayo Kobo conflict appeared to adhere to the official judiciary process of the bureaucratic state. They followed a protocol, conscientiously organized a delegation to the site to investigate the case and interview all parties involved (though they needed "motivation"), and referred to official laws and policies in their decisions. The delegation's findings and decisions were documented in official papers that were given to the Fulße Mare'en and the Tupuri and filed in the archives of the sous-prefecture. On the surface, the authorities seemed concerned about and committed to resolving the conflict between migrant Tupuri farmers and nomadic Fulße pastoralists. There was a pretense of bureaucratic practices that would resolve the conflict (Mbembe 2001). The problem was that no action was undertaken to enforce the sous-prefet's decision at the end of the growing season and consequently nothing changed and the conflict continued for two more years.

One could argue that the authorities did not undertake any effective action because it was politically unwise to remove the Tupuri farmers in the current political climate or that the state was weak and authorities lacked the financial means to enforce their decisions. Those reasons may have played a role, and again, it remains difficult to determine whether inaction is due to limited 
resources or "eating" by the local authorities (or both). My point is that the authorities had no incentives to resolve the conflict - a conflict that they themselves had created. The authorities stood to gain more by a continuation of the conflict than its resolution since they could collect rents from the Fulße Mare'en who wanted to continue the judiciary process to regain their campsites and from the Tupuri who wanted to slow the process to avoid their eviction. The lawan of Daram played a pivotal role in making the national lands productive for the authorities. First, he granted permission to the migrant Tupuri farmers to clear the campsites of the nomadic pastoralists in exchange for payments to him and the sous-préfet of Moulvoudaye. Then he assisted the Fulße Mare'en in the judiciary process and thus generated more income for himself and the souspréfet, who in turn shared some of it with other elites in Moulvoudaye by including them in the delegation.

The authorities were shrewd in the timing and organization of the process. Although few (if any) Tupuri and Fulße Mare'en trust the authorities, the lawan and the sous-prefet pretended convincingly enough that the judiciary process made sufficient progress to keep the conflicting parties invested (and investing). Their actions and words were enough to convince the Fulße Mare'en that there was a chance that they could reclaim their campsites and enough to spread fear and insecurity among the Tupuri farmers that they might lose their fields. The final decision of the sous-préfet was also cunning. On the surface, the sous-préfet's decision was resolute and clear: the Fulße Mare'en reclaimed their campsites and the Tupuri had to leave after the growing season. However, it also meant victories for both groups - the Fulße Mare'en had won and the Tupuri could stay - and thus motivated both groups to remain invested in the conflict. More importantly, the conflict was effectively unresolved and at the same time the stage was set for a continuation of the politics of permanent conflict in the year following when the Fulße Mare'en returned from their transhumance. Seen from the perspective of the authorities there was no ambiguity in who had the authority over the Mayo Kobo lands, as they cooperated and shared the spoils of conflict mediation in a reciprocal accommodation of elites. ${ }^{14}$ Authorities in the neopatrimonial state derive their power and income partly from arbitrage between different groups or networks (Cruise O'Brien, Dunn, and Rathbone 1989, 8; Bayart 1989, 41), and it is thus in their interest 
to create or perpetuate conflicts between these groups (Berry 1993, 130 ), and this is exactly what the authorities did in the Mayo Kobo conflict.

Herders and farmers coping with the belly politics are increasingly frustrated about the "appetite" of the authorities, in part because the payment of rents no longer guarantees a favorable outcome. ${ }^{15}$ The most likely outcome in conflicts over natural resources is a status quo, and this puts the party already in control of the natural resources at an advantage. The politics of permanent conflict thus reaffirm the existing West African pattern that farmers' usufruct rights are more secure than those of herders. But it has also increased the costs for farmers, as insecure land tenure requires constant "investments" in patrimonial networks. There is a growing sense among both herders and farmers that one never really wins if one goes to the authorities and as this awareness becomes more widespread one could possibly see more conflict resolution at a community level without the politics of the authorities. Although one has to keep in mind that "elites" among herders and farmers, including the jawro of the Tupuri village and the leaders of the Fulße Mare'en, have a stake in and play a supporting role in the politics of permanent conflict.

I have limited my discussion here to the role of authorities, but a similar actor-oriented analysis can be done of the herders and farmers involved in these conflicts. For example, it is frequently assumed that damages to farmer's crops are accidental, and often that is true. However, sending cattle into farmer's fields is also a deliberate feeding strategy used by herders to overcome the dry season crunch in the Sahel. In fact, Fulße pastoralists in the Far North believe that a good herder is a malicious herder, that is, one that takes good care of his animals by destroying farmers' crops. $^{16} \mathrm{I}$ have noted in the introduction that Ousmane's animals probably did not feed off the millet, even though he had to pay his share of the damages. The reason for this is that when Fulße herders purposively send cattle into fields, they will only let their own animals graze, while keeping those of others in the herd at bay. In that case, herders act as veritable rational actors by maximizing their profits while minimizing the costs. I have argued that integrating a strategic actor model and cost-benefit analyses in the study of farmerherder conflicts will lead to a better understanding of these conflicts. This is not just an academic exercise. Policies aimed at 
preventing farmer-herder conflicts - such as decentralization, comanagement, strengthening traditional institutions, pastoral charters, designation of land-use zones - are doomed to fail if they do not consider the politics of permanent conflict. They will merely change the rules with which the authorities play.

\section{Notes}

${ }^{1}$ Turner (nd) argues that a closer examination of farmer-herder conflicts may reveal that they are shaped by the political strategies of the people involved, particularly elites. But while Turner concludes that research should therefore focus on farmer-herder interactions as multi-stranded social relationships, I argue instead that we need to focus more on individual's strategic decision-making and behavior of all parties involved, including various authorities.

2 Bourdieu most likely would not have employed this "strategic actor" model, as he was a fierce critic of rational actor theory /or RAT as he called it) (Jenkins 1992). Despite his criticisms, his theoretical work supports a strategic actor model.

${ }^{3}$ The political system of neo-patrimonialism is seldom referenced in studies of land tenure and farmer-herder conflicts (for an exception see, Toulmin, Delville, and Traoré 2002, 10-11). Bassett (1988) mentions the clientelist political system in Cote d'Ivoire's, but it functions in his analysis of farmer-herder conflicts as a structural factor in the overall economy of the country, and not directly in the conflicts itself. Juul (2002) describes how Fulße pastoralists in Senegal use clientelistic networks to secure access to natural resources, but her analysis focuses on group strategies of Fulße pastoralists rather than the strategic actions of individual agents of the neopatrimonial state.

${ }^{4}$ Other anthropologists have also noted how power inequalities have led to accumulation of lands by "modern big men" in rural Africa (Goheen 1988; Downs and Reyna 1988; Shipton and Goheen 1992; Berry 1993); for a good discussion of how the "politics of the belly" affect farmers' access to land in northern Cameroon, see van den Berg (1997).

${ }^{5}$ The Diamare is a term that refers to a geographical area that generally includes Maroua and surroundings but the boundaries of the area change depending on what definition of the Diamare is employed (Seignobos et Tourneux 2002, 88-89). Here it refers to the plains between the Mandara Mountains, Logone Flood Plain, and Logone River conquered by the Fulße in the nineteenth century.

${ }^{6}$ The Fulße Mare'en are a sub-ethnic group of nomadic Fulße, meaning a group consisting of different clan fractions that have in common a migratory history and certain cultural traits (such as dialect, ceremonies, cattle 
breed, tents) (Burnham 1996). The Mare'en are referred to as Woyla'en ("the northern folks") by sedentary Fulße because they came originally from Borno, Nigeria. Only a small minority of the estimated 265000 Fulße in the Far North is nomadic, approximately two percent or five thousand (Seignobos et Iyébi-Mandjek 2000). Most of them came fairly recently from Niger and Nigeria, mainly during the droughts of 1973-74 and 1984. The Fulße Mare'en came to the Far North, about sixty years ago, which makes them the nomadic group with the longest presence in the Diamaré.

${ }^{7}$ The village head (jawro) of Gadjia, the village closest to Mayo Kobo was bypassed by both the Fulße Mare'en and the Tupuri. He had no power to intervene in conflicts as the sous-prefet and lawan always interfered and took away the case (and its spoils).

${ }^{8}$ Later it was established that the sites were located in the Daram lawanat, but the move of the Tupuri made the lawan of Daram proclaim that the Tupuri had paid bribes to get permission from the lawan of Kobo to clear the campsites that were not even located in his territory (van der Ploeg 2001).

9 Payer le carburant ("paying for fuel") is another Cameroonian euphemism for paying rents and bribes.

${ }_{10}$ The reoccurring crop damage did not directly lead to violent conflicts between Tupuri and Fulße Mare'en, but in 1998, a conflict over the theft of donkeys led to fatalities when Fulße herders entered a Tupuri village searching for the stolen animals. The build-up of anger and resentment between the two groups has been held responsible for the violent escalation (van der Ploeg 2001).

${ }^{11}$ Early during the conflict, the lawan of Daram had said that he could not do anything about the Tupuri farmers that had occupied the Mayo Kobo campsites because the Tupuri had grand hommes politiques and as a demographic group constituted a growing force in local politics of the area. He noted that many Tupuri do not ask him anymore for permission to clear lands in the bush; they go directly to the sous-préfet or even the preffet in Kaélé (van der Ploeg 2001).

12 Burnham $(1996,2045)$ notes similarly that the fines that Mbororo herders pay form an important source of income for Gbaya chiefs.

${ }^{13}$ It is possible that my work in Cameroon has colored my perspective (see Bayart 1993; Mbembe 2001; Takougang and Krieger 1998; Roitman 2003) and that the politics of the belly are more prominent in farmer-herder conflicts in Cameroon than elsewhere. It is noteworthy that neopatrimonial activities figure more prominently in the chapters that cover Cameroon than in those covering other West African countries in an edited volume on the dynamics of resource tenure in West Africa (Toulmin, Delville, and Traoré 2002).

${ }^{14}$ To a certain extent, the leaders $(a r D u B e)$ of the Fulße Mare'en also 
participated in the hegemonial assimilation of the elites. As representatives of nomadic pastoralists, the arDuBe took cuts from the taxes and tributes that they collected from their followers and transferred to the Fulße laamiiBe as part of the nomadic contract. It would probably go to far to argue that the nomadic leaders were interested in perpetuating the Mayo Kobo conflict - they were genuinely infuriated - but as representatives of the nomads, they certainly had an interest in the conflict. Failure to regain the campsites could always be blamed on the "outside world."

${ }^{15}$ Moreover, success in persuading the authorities does not depend on the money and/or services exchanged in one single transaction, but on the potential for exchanges in the future. This suggests that exchange and game theory are extremely relevant for the study of belly politics.

${ }^{16}$ Bononda, Fulfulde for "crop damages caused by animals," has the same verbal root as wongo (won-), which means "to be malicious" (Noye 1989, 387).

\section{Bibliography}

Amnesty International. 1998. Cameroon: Extrajudicial Executions in

North and Far-North Provinces

<http://web.amnesty.org/library/Index/ENGAFR170161998?open\&o $\mathrm{f}=\mathrm{ENG}$-CMR $>$. Accessed 9 February 2004.

Azarya, Victor. 1978. Aristocrats Facing Change: The Fulbe in Guinea,

Nigeria, and Cameroon. Chicago: University of Chicago Press.

$\rightarrow$ Bassett, Thomas J. 1988. "The Political Ecology of Peasant-Herder

Conflicts on the Northern Ivory Coast." Annals of the Association of American Geographers 78, no.3: 453-72.

Bayart, Jean-François. 1989. "Cameroon." In Contemporary West African

States, edited by D.B. Cruise O'Brien, J. Dunn and R. Rathbone. New York: Cambridge University Press.

- 1993. The State in Africa: Politics of the Belly. Harlow, UK:

Longman.

Bayart, Jean-François, Stephen Ellis, and Béatrice Hibou, eds. 1999. The

Criminalization of the State in Africa: African Issues. Oxford: The International African Institute, James Currey, Indiana University Press.

Beauvilain, Alain. 1989. Nord-Cameroun: crises et peuplement. Volumes

1 et 2 . Manches (France): Imprimerie Claude Bellee.

Benjaminsen, Tor A. and Christian Lund. 2001. "Politics, Property and

Production: Understanding Natural Resource Management in the West African Sahel." In Politics, Property and Production in the West African Sahel: Understanding Natural Resource Management, edited by T. A. Benjaminsen and C. Lund. Uppsala: Nordiska Afrikainstitutet. 
Berry, Sara. 1993. No Condition is Permanent: The Social Dynamics of Agrarian Change in Sub-Saharan Africa. Madison: University of Wisconsin Press.

Blaikie, Piers and Harold Brookfield. 1987. Land Degradation and Society. London: Methuen.

Bourdieu, Pierre. 1980 [1990]. The Logic of Practice. Translated by R. Nice. Stanford: Stanford University Press.

$\rightarrow$ Breusers, M., S. Nederlof, and T. van Rheenen. 1998. "Conflict or Symbiosis? Disentangling Farmer-Herdsman Relations: The Mossi and the Fulbe of the Central Plateau, Burkina Faso." Journal of Modern African Studies 36, no.3: 357-80.

Bryant, R.L. 1998. "Power, Knowledge, and Political Ecology in the Third World." Progress in Physical Geography 22: 79-94.

Bryant, R.L. and S. Bailey. 1997. Third World Political Ecology. London: Routledge.

Burnham, Philip. 1996. The Politics of Cultural Difference in Northern Cameroon. Washington DC: Smithsonian Institution Press.

Camerer, Colin. 1995. "Individual Decision Making." In The Handbook of Experimental Economics, edited by J.H. Kagel and A.E. Roth. Princeton: Princeton University Press.

Chabal, Patrick, and Jean-Pascal Daloz. 1999. Africa Works: Disorder as Political Instrument, African Issues. Oxford: The International African Institute, James Currey.

Cruise O'Brien, Donal B., John Dunn, and Richard Rathbone, eds. 1989. Contemporary West African States. New York: Cambridge University Press.

Downs, R. E. and Stephen P. Reyna. 1988. Land and Society in Contemporary Africa. Hanover: University Press of New England.

Ensminger, Jean. 1992. "Making a Market: The Institutional Transformation of an African Society." In The Political Economy of Institutions and Decisions, edited by J.E. Alt and D.C. North, Cambridge: Cambridge University Press.

Fisiy, Cyprian F. 1992. Power and Privilege in the Administration of Law: Land Law Reforms and Social Differentiation in Cameroon. Leiden: African Studies Centre.

Goheen, Miriam. 1988. "Land Accumulation and Local Control: the Manipulation of Symbols and Power in Nso, Cameroon." In Land and Society in Contemporary Africa, edited by R.E. Downs and S.P. Reyna. Hanover: Published for University of New Hampshire by University Press of New England.

$\rightarrow$ Granovetter, Mark. 1985. "Economic Action and Social Structure: The Problem of Embeddedness." American Journal of Sociology 91, no.3: 481-510. 
de Groot, Wouter T. 1998. "Problem-in-Context: A Framework for the Analysis, Explanation and Solution of Environmental Problems." In Environmental Management in Practice. Volume 1: Instruments for Environmental Management, edited by B. Nath, L. Hens, P.

Compton and D. Devuyst. London: Routledge.

Hagberg, Sten. 2001. "A l'ombre du conflit violent: règlement et gestion des conflits entre agriculteurs karaboro et agro-pasteurs peul au Burkina Faso." Cahiers d'etudes africaines 161, XLI, no. 1: 45-72.

$\rightarrow$ Hansen, Ketil Fred. 2003. "The Politics of Personal Relations: Beyond

Neopatrimonial Practices in Northern Cameroon." Africa 73, no.2: 202-25.

$\rightarrow$ Homer-Dixon, Thomas F. 1991. "On the Threshold: Environmental Changes as Causes of Acute Conflict." International Security 16, no.2: 76-116.

Horowitz, Leah Sophie. 2003. "Stranger in One's Own Home: A Micropolitical Ecological Analysis of the Engagements of Kanak Villagers with a Multinational Mining Project in New Caledonia." PhD thesis, Cultural Geography, School of Resources, Environment and Society, Australian National University, Melbourne.

Hussein, K., J. Sumberg, and D. Seddon. 2000. "Increasing Violent

Conflict Between Herders and Farmers in Africa: Claims and Evidence." Development Policy Review 17: 397-418.

Issa, Saibou et Hamadou Adama. 2002. "Vol et relations entre Peuls et

Guiziga dans la plaine du Diamaré (Nord-Cameroun)." Cahiers d'etudes africaines XLII, no.2: 359-72.

Jenkins, Richard. 1992. Pierre Bourdieu. London: Routledge. Juul, Kristin. 2002. "Post-drought Migration and the Quest for

Recognition: Asserting and Securing Claims among Fulani

Pastoralists in Northern Senegal." In Negotiating Property in Africa, edited by K. Juul and C. Lund. Portsmouth, New Hampshire:

Heinemann.

Kaplan, Robert D. 1994. "The Coming Anarchy: How Scarcity, Crime, Overpopulation, Tribalism, and Disease are Rapidly Destroying the Social Fabric of our Planet." The Atlantic Monthly, 44-65.

LeVine, Robert A. 1984. "Properties of Culture: An Ethnographic View." In Culture Theory: Essays on Mind, Self, and Emotion, edited by R.A. Schweder and R.A. LeVine. Cambridge: Cambridge University Press.

Long, N., and A. Long, eds. 1992. Battlefields of Knowledge: The Interlocking of Theory and Practice in Social Research and Development. London: Routledge.

Mbembe, Achille. 2001. On the Postcolony. Berkeley: University of California Press. 
McGlynn, F. and S. Tuden, eds. 1991. Anthropological Approaches to Political Behavior. Pittsburgh: University of Pittsburgh Press.

Mehta, L., M. Leach, P. Newell, I. Scoones, K. Sivaramakrishnan, and S.A. Way. 1999. "Exploring Understandings of Institutions and Uncertainty: New Directions in Natural Resource Management." IDS Discussion Paper 372.

Moritz, Mark, Paul Scholte, and Saidou Kari. 2002. "The Demise of the Nomadic Contract: Arrangements and Rangelands Under Pressure in the Far North of Cameroon." Nomadic Peoples 6, no.1: 127-46.

Mouiche, Ibrahim. 2000. "Ethnicité et multipartisme au Nord-

Cameroun." African Journal of Political Science 5, no.1: 49-91.

Noye, Dominique. 1989. Dictionnaire foulfouldé-français: dialecte Peul de Diamaré, Nord-Cameroun. Paris et Garoua: Geuthner et Procure des Missions.

Peluso, N. L. and M. Watts, eds. 2001. Violent Environments. Ithaca, New York: Cornell University Press.

Peters, Pauline E. 2002. "The Limits of Negotiability, Equity, and Class Formation in Africa's Land Systems." In Negotiating Property in Africa, edited by K. Juul and C. Lund. Portsmouth, New Hampshire: Heinemann.

Plattner, Stuart, ed. 1989. Economic Anthropology. Stanford: Stanford University Press.

Reno, William. 1995. Corruption and State Politics in Sierra Leone. Cambridge: Cambridge University Press.

Roitman, Janet L. 2003. "Unsanctioned Wealth: Or, the Productivity of Debt in Northern Cameroon." Public Culture 15, no.2: 211-37.

Rothchild, Donald. 1985. "State Ethnic Relations in Middle Africa." In African Independence: The First 25 years, edited by G. Carter and P. O'Meara. Bloomington: Indiana University Press.

Roy, Beth. 1994. Some Trouble with Cows: Making Sense of Social Conflict. Berkeley: University of California Press.

Seignobos, Christian et Olivier Iyébi-Mandjek, eds. 2000. Atlas de la province Extrême-Nord Cameroun. Paris: IRD et MINREST.

Seignobos, Christian et Henry Tourneux. 2002. Le Nord Cameroun à travers ses mots. Dictionnaire de termes anciens et modernes. Paris: Karthala.

$\rightarrow$ Sen, Amartya Kumar. 1977. "Rational Fools: A Critique of the Behavioral Foundations of Economic Theory." Philosophy and Public Affairs 6, no. $4: 317-44$.

$\rightarrow$ Shipton, Parker and Mitzi Goheen. 1992. "Understanding African Landholding: Power, Wealth, and Meaning." Africa 62, no.3: 307-25.

Takougang, Joseph and Milton Krieger. 1998. African State and Society in the 1990s: Cameroon's Political Crossroads. Boulder, Colorado: Westview Press. 
Toulmin, Camilla, Philippe Lavigne Delville, and Samba Traoré, eds. 2002. The Dynamics of Resource Tenure in West Africa. Oxford: James Currey.

Turner, Matthew D. 2002. "Moral Dimensions of 'Resource Struggles' and Their Treatment in Political Ecology." Association of American Geographers, Los Angeles.

- Nd. "Social Conflict and Natural Resources: The Case of Farmerherder Relations in West Africa." In Forests, Fields, and Fish: Politicized Indigenous Landscapes, edited by M. K. Steinberg. Austin: University of Texas Press.

van de Walle, Nicolas. 2001. African Economies and the Politics of Permanent Crisis, 1979-1999: Political Economy of Institutions and Decisions. Cambridge: Cambridge University Press. van den Berg, Adri. 1997. Land Right, Marriage Left: Women's Management of Insecurity in North Cameroon. Volume 54, CNWS Publications. Leiden: Research School CNWS, Leiden University. van der Ploeg, Jan. 2001. Lords of the Landscape: The Political Ecology of Peasant-herder Conflicts in the North of Cameroon. Leiden: Centre of Environmental Science, Leiden University.

Vayda, A.P. 1983. "Progressive Contextualization: Methods of Research in Human Ecology." Human Ecology 11: 265-81.

Vayda, Andrew P. and Bradley B. Walters. 1999. "Against Political Ecology." Human Ecology 27, no.1: 167-79.

Wassouni, W. 2001. "Managing a Fragile Environment: Bush Reduction and Conflicting Interests in the Mindif Region (Extreme North Cameroon)." In Management of Fragile Ecosystems in the North of Cameroon: The Need for an Adaptive Approach. Proceedings of an International Conference, Maroua 13-16 November 2000, edited by M. Ali, P. Loth, H. Bauer and H. de Iongh. Maroua, Cameroon and Leiden, Netherlands: CEDC and CML.

Watts, Michael J. 2000. "Political Ecology." In A Companion to Economic Geography, edited by T. Barnes and E. Sheppard. Oxford: Blackwell.

Wilk, Richard R. 1996. Economies and Cultures: Foundations of Economic Anthropology. Boulder, Colorado: Westview Press. 